\title{
Influence of Sea Level Pressure on Inter-Annual Rainfall Variability in Northern Senegal in the Context of Climate Change
}

\author{
Aichetou Dia-Diop1, Malick Wade1 ${ }^{*}$, Sinclaire Zebaze², Abdoulaye Bouya Diop", \\ Eric Efon ${ }^{3}$, Andre Lenouo², Bouya Diop ${ }^{1}$ \\ ${ }^{1}$ Laboratoire des Sciences de l'Atmosphère et des Océans-Matériaux-Énergie-Dispositifs (LSAO-MED), Université Gaston \\ Berger, Saint-Louis, Sénégal \\ ${ }^{2}$ Department of Physics, Faculty of Science, University of Yaoundé 1, Yaoundé, Cameroon \\ ${ }^{3}$ Department of Physics, Faculty of Science, University of Bamenda, Bamenda, Cameroon \\ Email: ${ }^{\star}$ malick.wade@ugb.edu.sn
}

How to cite this paper: Dia-Diop, A., Wade, M., Zebaze, S., Diop, A.B., Efon, E., Lenouo, A. and Diop, B. (2022) Influence of Sea Level Pressure on Inter-Annual Rainfall Variability in Northern Senegal in the Context of Climate Change. Atmospheric and Climate Sciences, 12, 113-131. https://doi.org/10.4236/acs.2022.121009

Received: October 20, 2021

Accepted: January 4, 2022

Published: January 7, 2022

Copyright $\odot 2022$ by author(s) and Scientific Research Publishing Inc. This work is licensed under the Creative Commons Attribution International License (CC BY 4.0).

http://creativecommons.org/licenses/by/4.0/

\begin{abstract}
This study examines the inter-annual variability of rainfall and Mean Sea Level Pressure (MSLP) over west Africa based on analysis of the Global Precipitation Climatology Project (GPCP) and National Center for Environmental Prediction/National Center for Atmospheric Research (NCEP/NCAR) Reanalysis respectively. An interconnection is found in this region, between Mean Sea Level Pressure (MSLP) anomaly (over Azores and St. Helena High) and monthly mean precipitation during summer (June to September: JJAS). We also found that over northern Senegal $\left(15^{\circ} \mathrm{N}-17^{\circ} \mathrm{N} ; 17^{\circ} \mathrm{W}-13^{\circ} \mathrm{W}\right)$ the SLP to the north is strong; the wind converges at $200 \mathrm{hPa}$ corresponding to the position of the African Easterly Jet (AEJ) the rotational wind $700 \mathrm{hPa}$ (corresponding to the position of the African Easterly Jet (AEJ) coming from the north-east is negative. In this region, the precipitation is related to the SLP to the north with the opposite sign. The Empirical Orthogonal Functions (EOF) of SLP is also presented, including the mean spectrum of precipitation and pressures to the north $\left(15^{\circ} \mathrm{N}-40^{\circ} \mathrm{N}\right.$ and $\left.50^{\circ} \mathrm{W}-25^{\circ} \mathrm{W}\right)$ and south $\left(40^{\circ} \mathrm{S}-\right.$ $10^{\circ} \mathrm{S}$ and $\left.40^{\circ} \mathrm{W}-0^{\circ} \mathrm{E}\right)$. The dominant EOF of Sea Level Pressures north and south of the Atlantic Ocean for GPCP represents about $62.2 \%$ and $69.4 \%$ of the variance, respectively. The second and third EOFs of the pressure to the north account for $24.0 \%$ and $6.5 \%$ respectively. The second and third EOFs of the pressure to the south represent $12.5 \%$ and $8.9 \%$ respectively. Wet years in the north of Senegal were associated with anomalous low-pressure areas over the north Atlantic Ocean as opposed to the dry years which exhibited an anomalous high-pressure area in the same region. On the other hand, over the South Atlantic, an opposition is noted. The wavelet analysis method is
\end{abstract}


applied to the SLP showings to the north, south and precipitation in our study area. The indices prove to be very consistent, especially during intervals of high variance.

\section{Keywords}

Global Precipitation Climatology Project (GPCP), West Africa monsoon, Inter-Tropical Convergence Zone, African Easterly Jet (AEJ), Tropical Easterly Jet (TEJ), Sea Level Pressure (SLP)

\section{Introduction}

The Sahel is an area of the semi-arid expanse of meadows, shrubs and small thorny trees found in the Southern Sahara Desert [1]. This region stretches to about $5000 \mathrm{~km}$ through Africa from east to west, more precisely, the term "Sahel" applies to a small region between latitudes $14^{\circ} \mathrm{N}$ and $18^{\circ} \mathrm{N}$. It consists of countries like Sudan, Chad, Mali, Senegal, Niger, Mauritania, Burkina Faso (the northern part), and Nigeria (the northern part). Most of the local population of this region live in rural areas and practice agriculture. Thus, the variability of climatic parameters is of great importance for the region. The specific study area, i.e. Senegal (Figure 1), has two anticyclones: the Azores and Saint Helena. Taking monthly time-step, with no connection with ocean temperatures, [2] initiated a series of studies by showing the Azores anticyclone's inhibitory influence on the Sahelian precipitation. The enhanced effect of their coupling, a strong Azores anticyclone and a weak St. Helena anticyclone leads to an enhanced rainfall deficit over the Sahel and vice versa. [3] showed that during the wet regime, there is a substantial variance in the seasonal modes linked to the Inter-Tropical Convergence Zone (ITCZ) and multi-annual modes succeeding

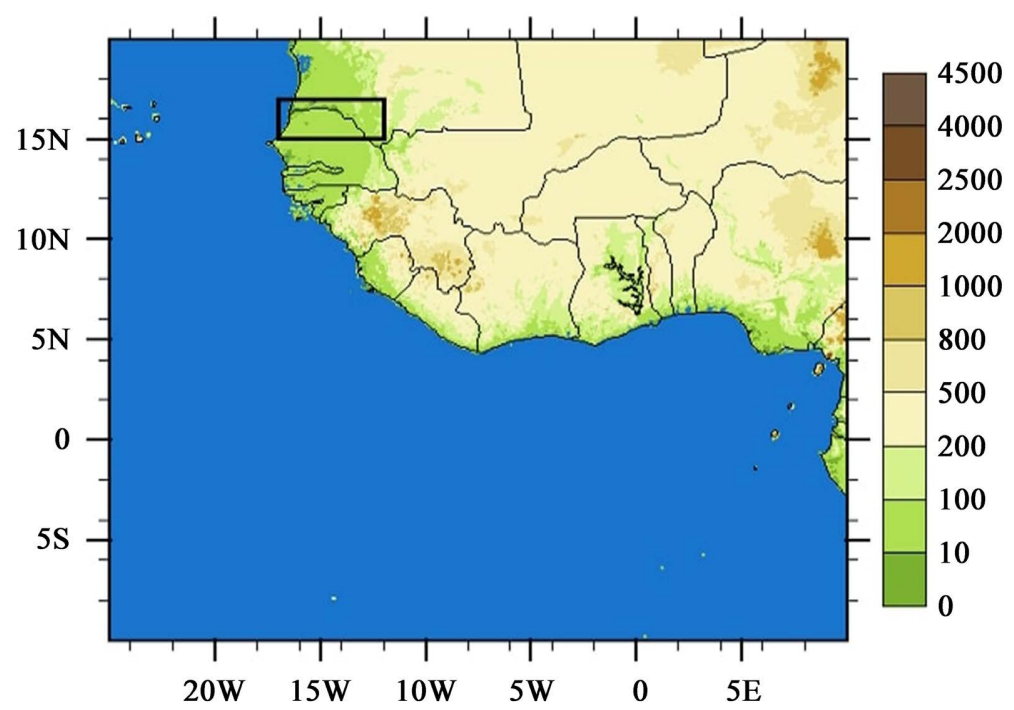

Figure 1. Topography (m) of West Africa, the Atlantic Ocean and some African continents are shown. Box indicates the study area of the northern of Senegal region. 
each other over time (5 - 8 years then 2 - 4 years) in association with temperatures of the North Tropical Atlantic (TNA) then with the Anticyclone of the Azores. [4] showed that about $50 \%$ of the variance in July-September rainfall over the Sahel is explained by changes in the high longitude position of the Azores and low pressure in South Asia.

The hot phase of Enoa is manifested by a weakening of the gradient of pressure anomalies between the east and west of the Pacific and a decrease in the east-west flux of the trade winds, phenomena associated with persistent warming of the eastern and central equatorial Pacific. The opposite phenomena manifest the cold phase of the Enoa: increase in the zonal pressure gradient and the flux of trade winds associated with persistent cooling in the central equatorial Pacific. This phenomenon has a considerable impact on temperature and precipitation fields [5] and is particularly noticed around the Pacific and the Indian Ocean. However, the peri-Atlantic regions are also concerned since Enoa is also associated with the variability of sea surface temperatures and trade winds over the tropical Atlantic ([6] [7] [8]).

Since temperatures and sea surface pressure are linked, it is necessary to investigate the interaction between precipitation and MSLP to assess their modification in the West African Sahel's climate system, especially over northern Senegal. [9] showed that the existence of cooler (warmer) TSOs in the Atlantic Ocean is overcome by an increase (decrease) in the pressure field. The choice of SLP comes from the analysis of [10] who showed that pressure is the most sensitive to the influence of Sea Surface Temperature (SST).

In this paper, datasets and methods used are briefly described in Section 2. Section 3 investigates the characteristic of precipitation and the annual cycle associated with MSLP. Finally, Section 4 summarizes the main results and gives some prospects for future work.

\section{Data and Methods}

\subsection{Data}

Precipitation data used was derived from the Global Precipitation Climatology Project (GPCP) version 2.2. The GPCP analyses are derived from rain gauge stations, satellites, and sounding observations that have been merged. The data is available from 1979 to the present at $2.5^{\circ}$ resolution [11]. This dataset consists of a combination of all precipitation data from polar satellites (estimates of The Special Sensor Microwave Imager (SSMI/I) emissions) and the precipitation data centre of geostationary satellites of the GPCP (estimated rain gauge GPI and OPI). This data product has been validated regionally and globally by [12] and [13]. The ERA-Interim (ERA-I) reanalysis of European Centre for Medium-Range Weather Forecasts (ECMWF, [14]), available from 1979 to present with a spatial resolution of $0.75^{\circ} \times 0.75^{\circ}$ were used. The variables are specific humidity, zonal and meridional wind component. We also use the monthly SLP from the National Center for Environmental Prediction/National Center for Atmospheric 
Research (NCEP/NCAR) Reanalysis Project available for the period 1979 to the present at $2.5^{\circ}$ resolution.

\subsection{Methodology}

Wavelet analysis is a standard tool for decomposing a time series into a timefrequency space and detecting time-frequency variations. The wavelet transformation makes it possible to compare a signal with a wavelet function called mother wavelet [15]. After having tested different mother wavelets, the results obtained are similar. As the wavelet transform is a band-pass filter with a known response function (the wavelet function), it is also a powerful filtering technique. To identify the dominant modes, the wavelet analysis method is used during the period 1979-2003 in the study area (Figure 1).

The Orthogonal Empirical Function (EOF), also called Principal Component Analysis (PCA) is a multivariate statistical technique that consists in reducing a dataset containing a large number $(K \times 1)$ of data vectors to a dataset containing fewer new $(M \times 1)$ variable vectors $u$, which are linear combinations of the original vectors and which contain most of the information from the original collection of $x$. The elements of these new vectors $u$ are called the principal components (PC). Most often, the main component is calculated using anomalies. The first PC, $u_{1}$, is the linear combination of $x^{\prime}$ with the most significant variance. The following main component $u_{m}, m=2,3,4, \ldots$, are the linear combinations having the most significant possible variance, provided that they are not correlated with the main components having lower indices.

The $m^{\text {th }}$ principal component of the elements $u_{m}$ of $u$ is obtained by the projection of the data vector $x^{\prime}$ on the $m^{\text {th }}$ eigenvector, $e_{m}$, of the covariance matrix of $x$, [S], by the relationship (Wilks, 2011):

$$
u_{m}=e_{m}^{\mathrm{T}} x^{\prime}=\sum e_{k, m} x_{k}^{\prime}, \quad m=1,2, \cdots, M
$$

where the transposition operation is denoted by the exponent $\mathrm{T}$, and each of the $M$ eigenvectors contains an element relating to each of the $K$ variables, $X_{m}$.

Other methods involve analyzes of the main characteristics of spatial variability (generally given by the most important empirical orthogonal function models (EOF)), and large-scale mechanisms controlling the regional climatic variability given by the canonical correlation ([16] [17] [18] [19]).

\section{Results and Discussion}

Figure 1 shows the topography (m) of West Africa, the Atlantic Ocean and some African continents. The rectangle indicates the study area of the northern region of Senegal. From Figure 1, the study area is between $15^{\circ} \mathrm{N}-17^{\circ} \mathrm{N}$ and $17^{\circ} \mathrm{W}-13^{\circ} \mathrm{W}$. The study area is bordered to the west by the Atlantic Ocean; this justifies the study of Sea Level Pressure (SLP). To understand the different levels of sea level pressure used in the literature Figure 2 is shown.

Figure 2 shows the average global surface pressure. The study area, which is located in the north part of West Africa, is surrounded by two anticyclones, be- 
tween $15^{\circ} \mathrm{N}-60^{\circ} \mathrm{N}$ and $90^{\circ} \mathrm{W}-05^{\circ} \mathrm{W}(1010 \mathrm{hPa})$ and $40^{\circ} \mathrm{S}-10^{\circ} \mathrm{S}$ and $30^{\circ} \mathrm{W}-$ $0^{\circ} \mathrm{E}(1020 \mathrm{hPa})$. To explain the precipitation trend changes, [20] consider the response precipitation to the $\mathrm{NAO}$, the regression between sea level pressure (SLP) over the Euro-Atlantic area onto precipitation. Figure 1 allows us to show that our study area, northern Senegal, is surrounded by two high sea level pressures, namely the Azores High and the St. Helena High. Since our study focuses on the influence of these two high-pressure areas, this figure allows us to locate the coordinates of these high-pressure areas in relation to our zone.

As the study is based on the influence of sea-level pressure on interannual variability, is interesting to see how surface pressure varies in different months.

Figure 3 shows the monthly average of Sea Level Pressure. It is observed that SLP, varying between $1006-1016 \mathrm{hPa}$ over $20^{\circ} \mathrm{S}$ and $20^{\circ} \mathrm{N}$ and $1018-1022 \mathrm{hPa}$

\section{Zonal Average}

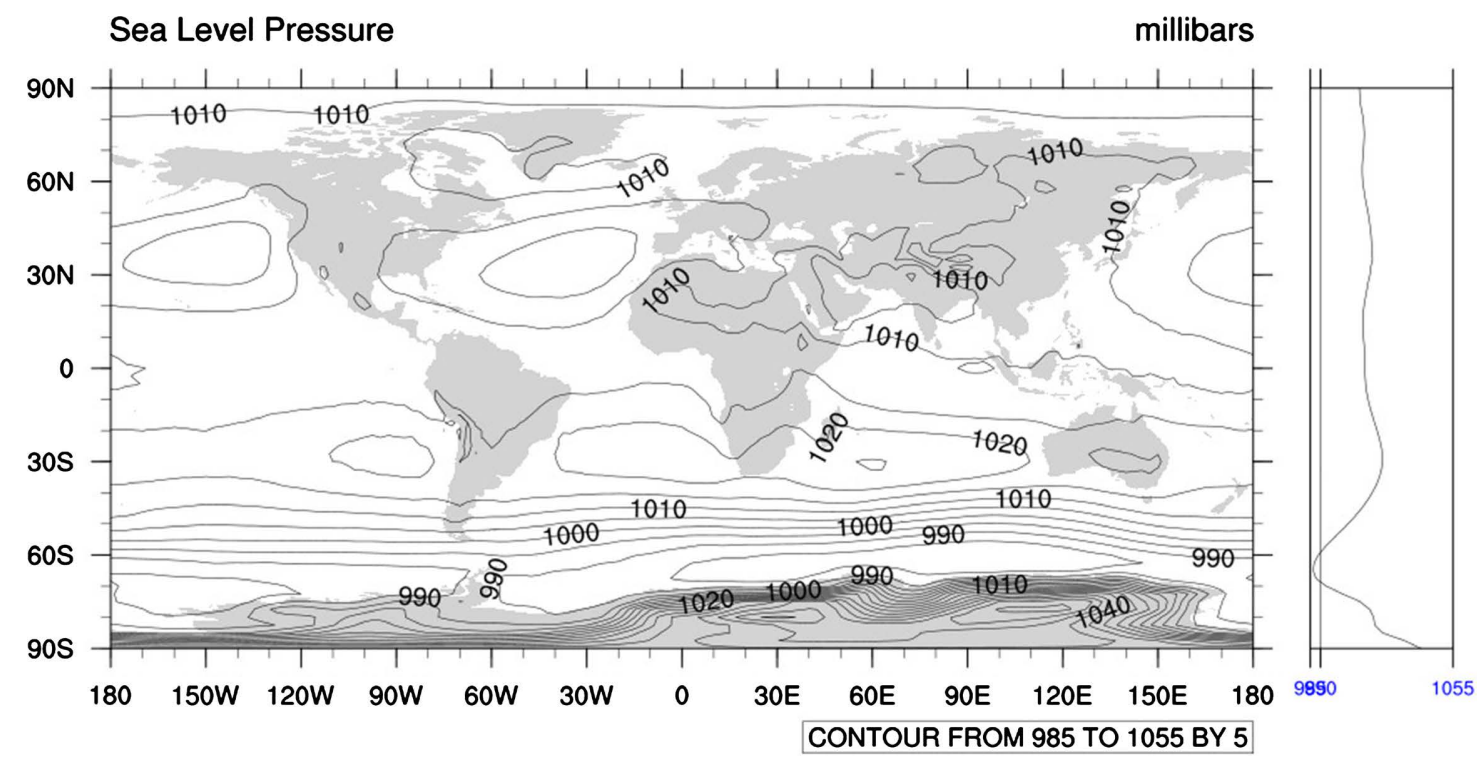

Figure 2. Global average of Sea Level pressure for the period $1979-2003$. between $30^{\circ} \mathrm{S}-30^{\circ} \mathrm{N}$ and $40^{\circ} \mathrm{W}-30^{\circ} \mathrm{E}$. The pressures are in millibars.
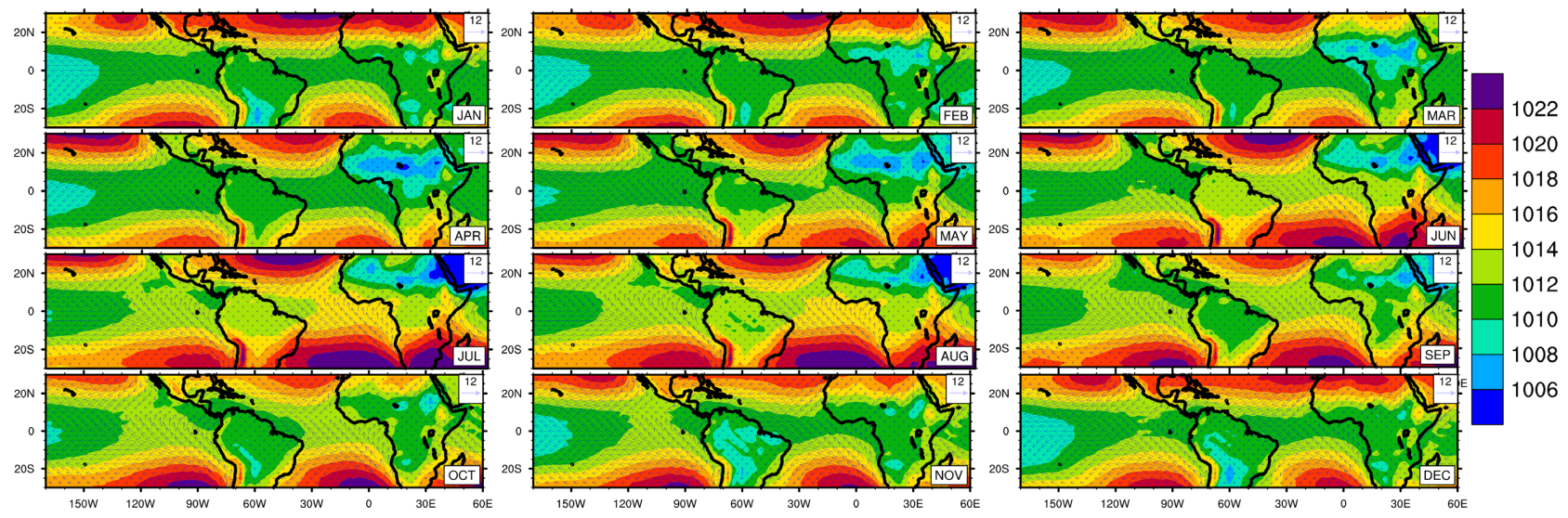

Figure 3. Monthly average (shaded, hPa) of the Sea Level Pressure for the $1979-2003$ period between $30^{\circ} \mathrm{S}-30^{\circ} \mathrm{N}$ and $180^{\circ} \mathrm{W}-$ $60^{\circ} \mathrm{E}$. The pressures are in millibars. 
beyond $20^{\circ} \mathrm{N}$ and below $20^{\circ} \mathrm{S}$. The southerly high pressure of $1022 \mathrm{hPa}$ or greater approached $20^{\circ} \mathrm{S}$ and sea level longitude (located between the continents of Africa and America) from June to October. This period corresponds to the rain belt defined by [21]. While the northern one approaches the $20^{\circ} \mathrm{N}$ zone and the sea longitude (located between the two continents Africa and America) from June to July. The high-pressure system in the south becomes lower than 1022 $\mathrm{hPa}$ from August to October. This figure of the mean monthly pressure indicates the relationship of the Sea Level Pressure with the seasonal cycle of precipitation in our study area. [22] showed that the pressure adjustment mechanism is the main driver of the convergence of meridional surface winds in the eastern tropical Atlantic.

The deficit of rainfall was associated with an increase in the subsidence of the air and a surplus with a more intense monsoon circulation. It is necessary to look at the wind characteristics at $700 \mathrm{hPa}$ and $200 \mathrm{hPa}$. The wind at these two pressure levels plays an important role in the interannual variability of rainfall. They correspond to the position of the African Easterly Jet (AEJ) and the Tropical Easterly Jet (TEJ). In Figure 3, it can be seen that the SLP to the north and the south accompanies the rainfall belt. It is necessary to represent the Sea Level Pressure in JJAS.

Figure 4(a) shows the $700 \mathrm{hPa}$ average wind (JJAS) and GPCP precipitation (JJAS) while Figure 4(b) shows the divergence of the wind (JJAS) at $700 \mathrm{hPa}$ (vectors) and the Sea Level Pressure (JJAS). The mean wind (JJAS) at $200 \mathrm{hPa}$ (vectors) and precipitation from GPCP (JJAS), the wind divergence (JJAS) at 200 hPa (vectors) and the Sea Level Pressure (JJAS) are shown in Figure 4(c) and Figure 4(d), respectively. Maximum precipitation accompanies the mean east wind of the northern hemisphere, which corresponds to the African Easterly Jet (JEA) $(700 \mathrm{hPa})$ and the Tropical Easterly Jet (JET) $(200 \mathrm{hPa})$. The high pressure located between $25^{\circ} \mathrm{N}-40^{\circ} \mathrm{N}$ and $50^{\circ} \mathrm{W}-20^{\circ} \mathrm{W}$ is accompanied by the wind subsidence at $700 \mathrm{hPa}$ and $200 \mathrm{hPa}$. [23] have shown that the forecast rainfall deficits towards the west are associated with an increase in air subsidence and the surplus with a more intense monsoon circulation and a reinforcement of the Africa Easterly Jet and anomalies in the zonal circulation between the Indian and Atlantic oceans, favouring the subsidence of the air and the transfer of humidity outside the region. The wind convergence is observed at $200 \mathrm{hPa}$ over $\left(15^{\circ} \mathrm{N}\right.$ $17^{\circ} \mathrm{N} ; 17^{\circ} \mathrm{W}-12^{\circ} \mathrm{W}$ ). [24] established a link between low-level divergence of the upper troposphere above West Africa with a strengthening of the Walker-type atmospheric cell above the Atlantic and the occurrence of droughts affecting the whole of West Africa.

Figure 4(e) and Figure 4(f) show the rotational wind at $700 \mathrm{hPa}$ and at 200 $\mathrm{hPa}$. It can be seen that the sea surface pressure (greater than or equal to 1015 $\mathrm{hPa})$ is located between two zones $\left(10^{\circ} \mathrm{S}-40^{\circ} \mathrm{S}\right.$ and $40^{\circ} \mathrm{W}-0^{\circ} \mathrm{E}$, and $15^{\circ} \mathrm{N}-40^{\circ} \mathrm{N}$ and $50^{\circ} \mathrm{W}-25^{\circ} \mathrm{W}$ ). It is found that the rotational wind at $700 \mathrm{hPa}$ is from the northeast, i.e., of negative sign. This weakness is synonymous with a minimum 
(a) Mean (JJAS)

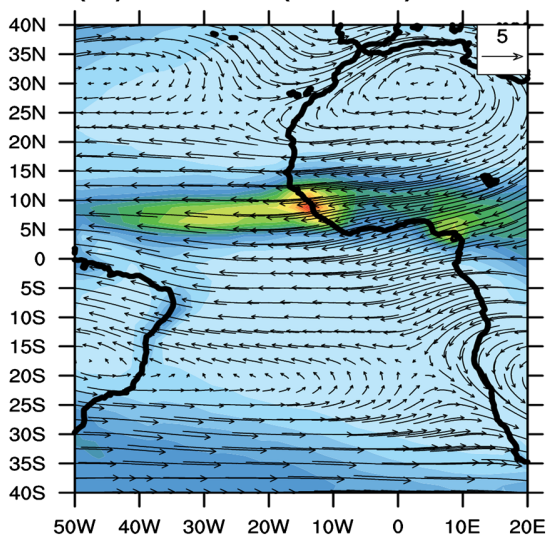

$\begin{array}{lllllllllll}2 & 4 & 6 & 8 & 10 & 12 & 14 & 16 & 18 & 20\end{array}$

(c) Mean (JJAS)

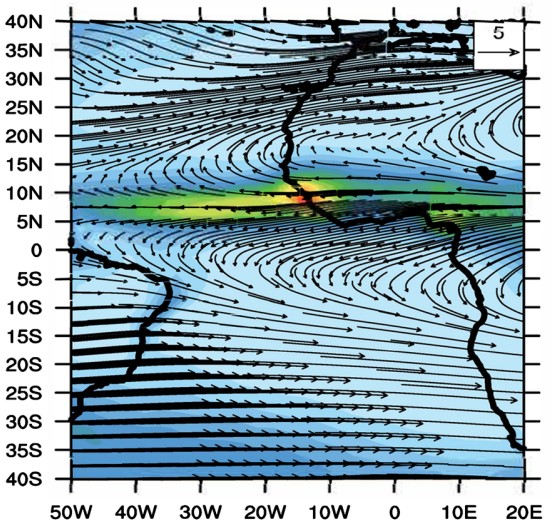

$24 \begin{array}{llllllllll}2 & 6 & 8 & 10 & 12 & 14 & 16 & 18 & 20\end{array}$ (b) Mean (JJAS)
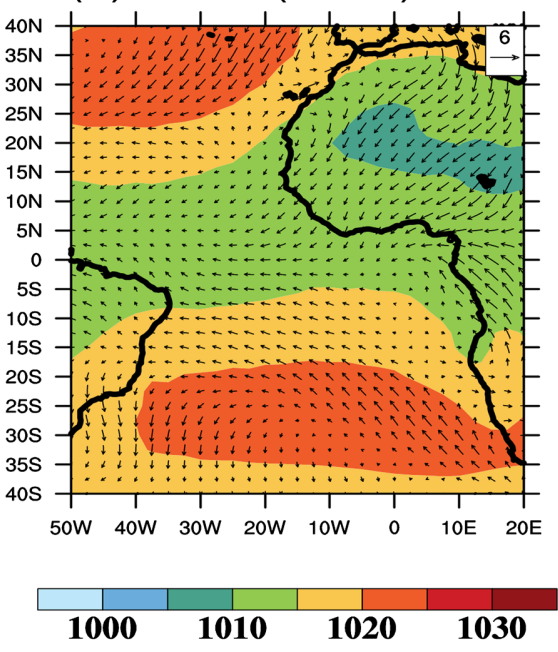

(d) Mean (JJAS)
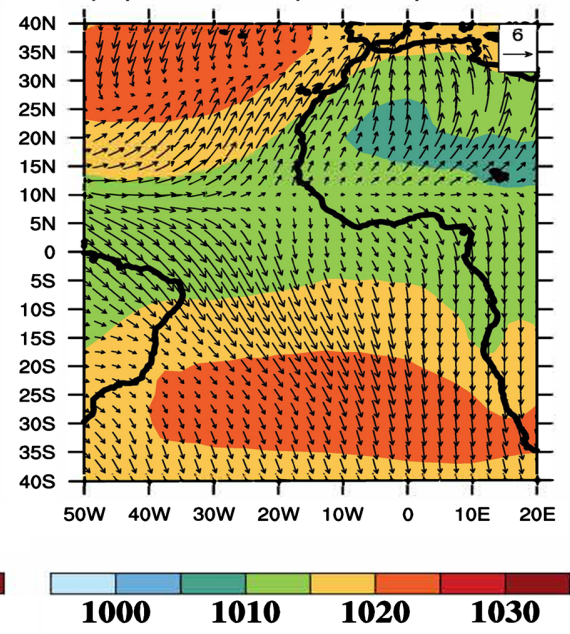

(f) Mean (JJAS)

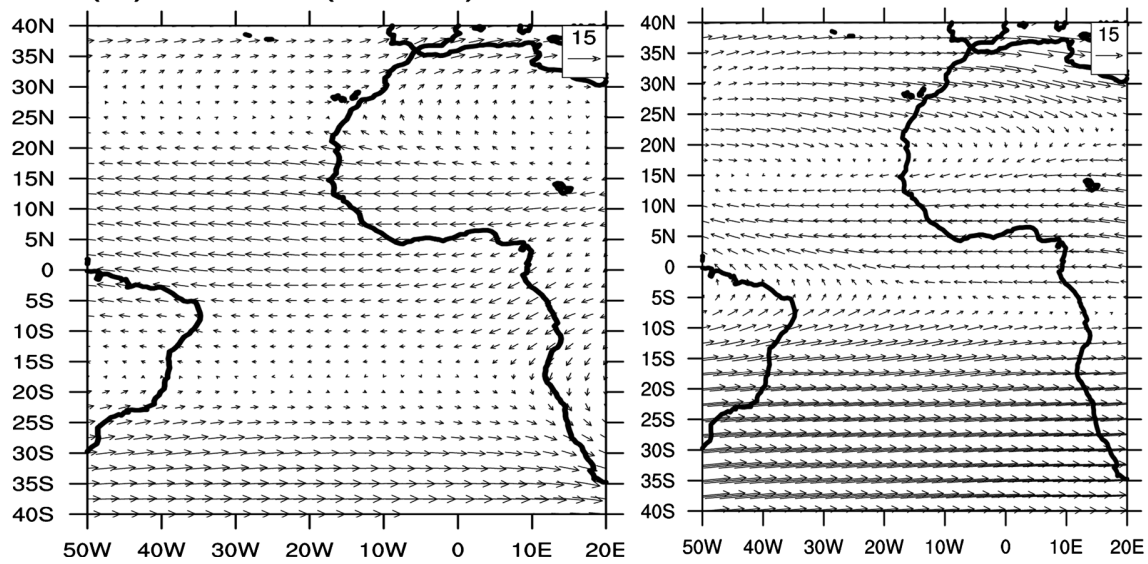

Figure 4. (a) Mean wind (vector, $\mathrm{m} / \mathrm{s}$ ) at $700 \mathrm{hPa}$ and precipitation (shaded, $\mathrm{mm} /$ day), (b) divergence of wind at $700 \mathrm{hPa}$ (vector, $\mathrm{m} / \mathrm{s}$ ) and SLP (shaded, hPa), (c) mean wind at $200 \mathrm{hPa}$ (vector, $\mathrm{m} / \mathrm{s}$ ) and GPCP precipitation (shaded, $\mathrm{mm} /$ day), (d) Wind divergence at $200 \mathrm{hPa}$ (vector, $\mathrm{m} / \mathrm{s}$ ) and SLP (shaded, $\mathrm{hPa}$ ), (e) Rotational wind (vector, $\mathrm{m} / \mathrm{s}$ ) at $700 \mathrm{hPa}$ and SLP (hPa) and (f) rotational wind at $200 \mathrm{hPa}$ and SLP (in hPa). 
vortex. [25] has shown that a maximum of relative vortex marks the increase in cyclonic circulation linked to the continental thermal depression. The figure illustrates the Inter-Tropical Convergence Zone (ITCZ) defined as the zone into which the converging fluxes from the subtropical anticyclones move: The Saint Helena high (southern hemisphere), and the Azores and Saharo-Lybian (northern hemisphere) high. The ITCZ corresponds to the low-pressure area between the subtropical high-pressure belts [26]. It was found that there is probably a relationship between Sea Level Pressure and precipitation. In this study, we aim to highlight the statistical relationship between these two variables.

Figure 5 shows the correlation between SLP and JJAS precipitation between $5^{\circ} \mathrm{S}-20^{\circ} \mathrm{N}$ and $20^{\circ} \mathrm{W}-0^{\circ} \mathrm{W}$. There is a negative correlation over $15^{\circ} \mathrm{N}-17^{\circ} \mathrm{N}$ and $17^{\circ} \mathrm{W}-13^{\circ} \mathrm{W}$. This figure also indicates that, in the study area, SLP is related to precipitation with the opposite sign (i.e. higher values of sea surface pressure in the north are accompanied by a decrease in precipitation). [24] showed that a deficit season in the Sahel occurs when there is a "dipolar" structure of surface pressure (higher values in the North Atlantic, lower values in the South Atlantic). [27] have shown that climate change in the West African monsoon region in autumn is due to increased pressure with abnormally high-pressure circulation over Europe.

The two levels of sea pressure were identified in Figure $4\left(10^{\circ} \mathrm{S}-40^{\circ} \mathrm{S}\right.$ and $40^{\circ} \mathrm{W}-0^{\circ} \mathrm{E}$, and $15^{\circ} \mathrm{N}-40^{\circ} \mathrm{N}$ and $\left.50^{\circ} \mathrm{W}-25^{\circ} \mathrm{W}\right)$. The PCs of these SLP are

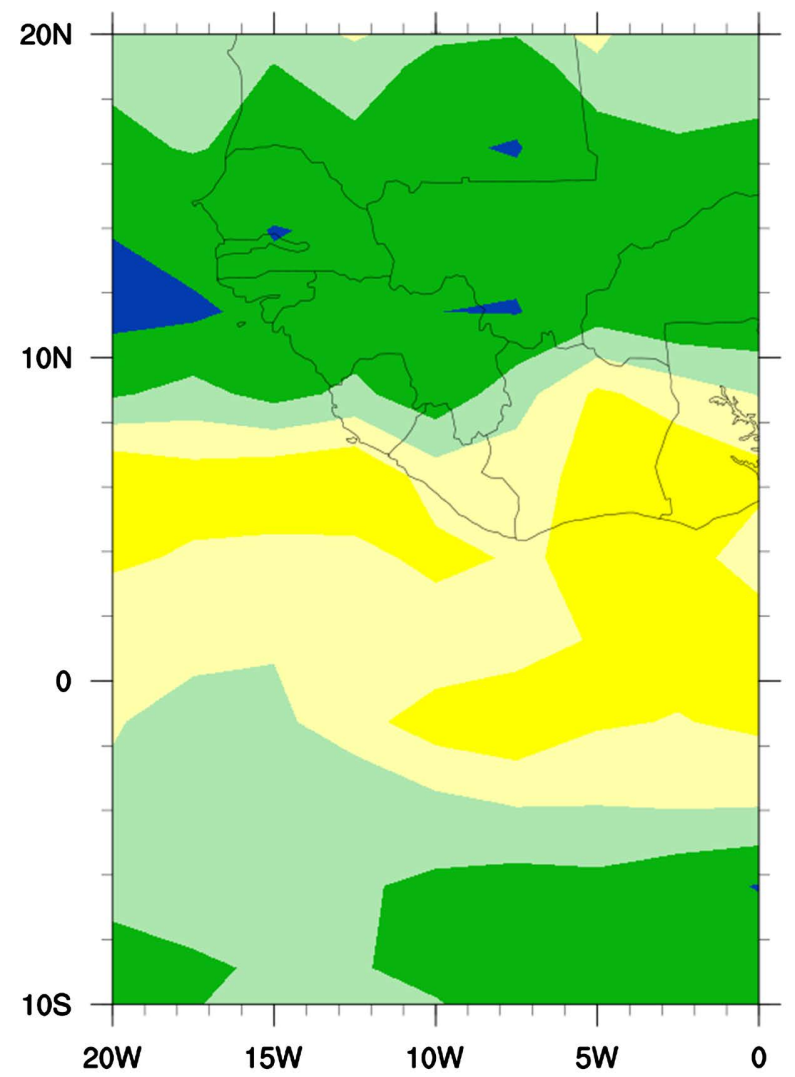

Figure 5. Correlation between sea surface pressure and JJAS precipitation 1979-2003. 
shown in Figures 6-9.

Figure 6 shows the first three PCs of the SLP data between $15^{\circ} \mathrm{N}-40^{\circ} \mathrm{N}$ and $50^{\circ} \mathrm{W}-25^{\circ} \mathrm{W}$ during summer (JAS) from 1979 to 2003 . PC1 is in a negative phase for the years 1979-1984, 1990-1994, 1996-1997, and 2002. These components account for $62.2 \%$ of the total variance. The PC2 of SLP data was generally in its positive phase for the years 1981, 1983, 1986-1987, 1991-1994, 1997 and

\section{SLP: JAS: 1979-2003}
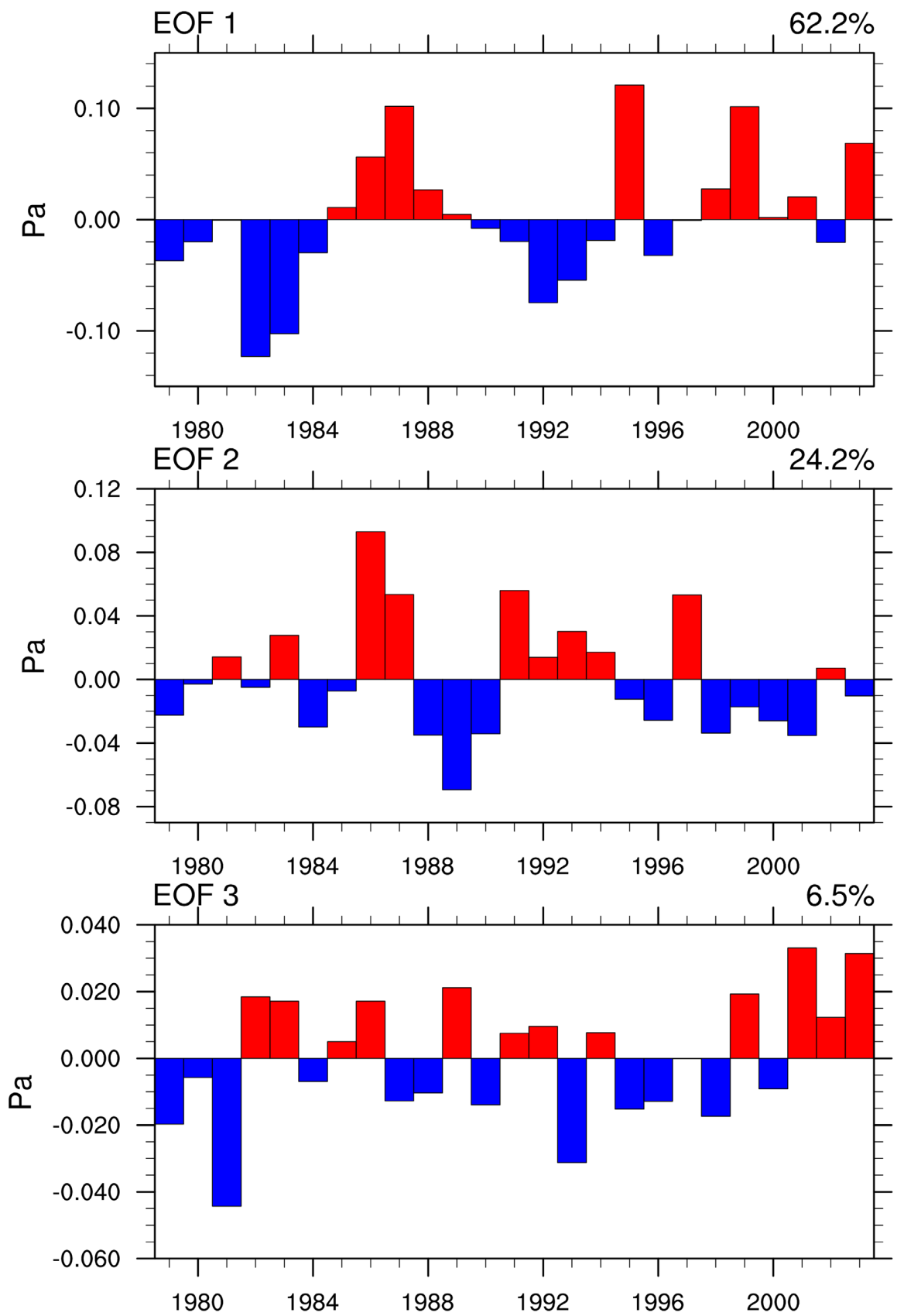

Figure 6. The first three PCs of SLP data between $15^{\circ} \mathrm{N}$ and $40^{\circ} \mathrm{N}$ and $50^{\circ} \mathrm{W}$ and $25^{\circ} \mathrm{W}$ during June, July and August for 1979-2003. The percentage of the total variance explaining the pattern appears in the upper right corner. 

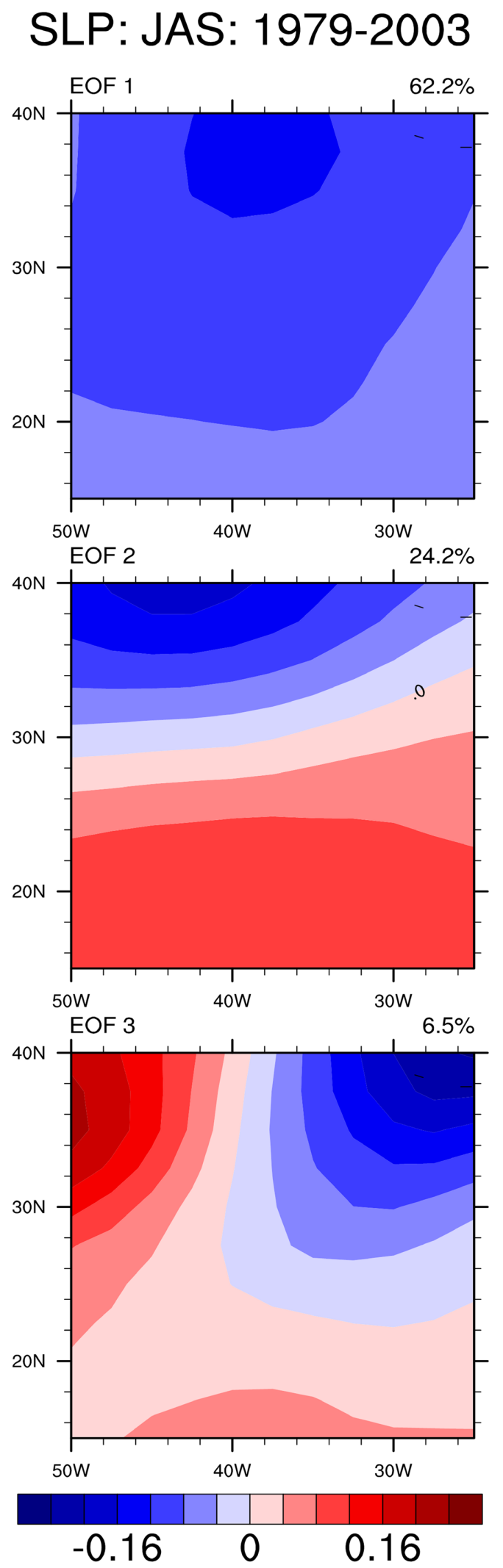

Figure 7. EOF of SLP data on between $15^{\circ} \mathrm{N}-40^{\circ} \mathrm{N}$ and $50^{\circ} \mathrm{W}-25^{\circ} \mathrm{W}$ during June, July and August for 1979-2003. The percentage of the total variance explaining the pattern appears in the upper right corner. 
SLP: JAS: 1979-2003

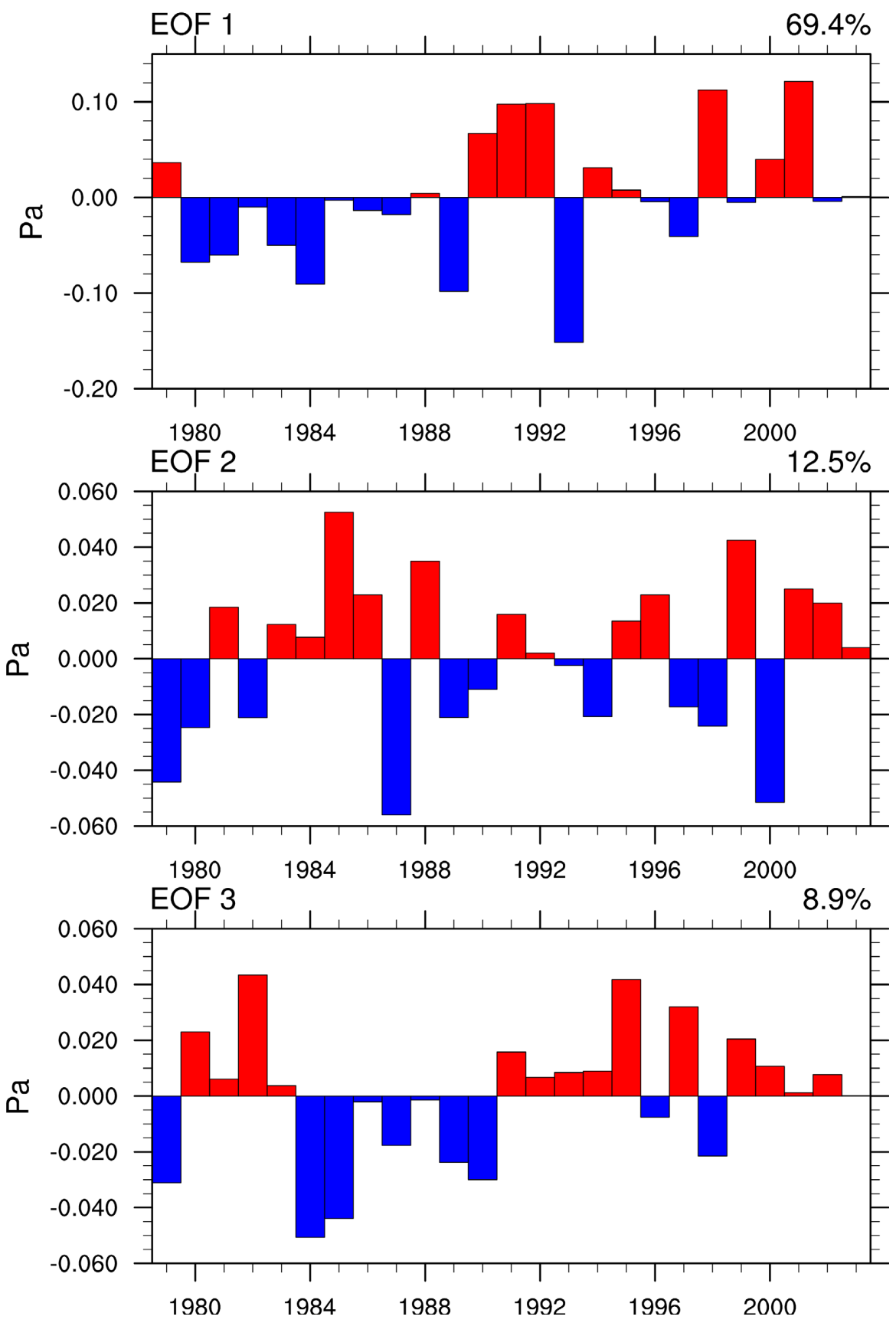

Figure 8. The first three PCs of SLP data on $40^{\circ} \mathrm{S}-10^{\circ} \mathrm{S}$ and $40^{\circ} \mathrm{W}-0^{\circ} \mathrm{E}$ during June, July and August for 1979-2003. The percentage of the total variance explaining the pattern appears in the upper right corner.

2002 while the PC3 of SLP data was in its negative phase between the years 1979-1981, 1984, 1987-1988, 1990, 1993, 1995-1998 and 2000 and in its positive phase between 1982-1983, 1985-1986, 1989, 1991-1992, 1994, 1999 and 2001-2003. The years 1982-1983 corresponded to years of drought in our study area. [28] showed that any strengthening or displacement towards the south of the Azores anticyclone causes a southward shift of the ITCZ. PC2 and PC3 re- 
spectively represent approximately $24.2 \%$ and $6.5 \%$ of the total variance. The first three corresponding EOFs are shown in Figure 7.

Figure 6 shows the temporal component while Figure 7 shows the spatial component. PC1 is negative over the entire area representing $62.2 \%$. PC2 is negative between $28^{\circ} \mathrm{N}-40^{\circ} \mathrm{N}$ and positive between $15^{\circ} \mathrm{N}-28^{\circ} \mathrm{N}$ showing a north-south dipole. PC3 is positive between $50^{\circ} \mathrm{W}-25^{\circ} \mathrm{W}$ and $15^{\circ} \mathrm{N}-24^{\circ} \mathrm{N}$. Our study area is located in this zone. According to Figure 6, PC3 was in its positive 1982-1983; this period corresponds to a period of drought in our study zone. The SLP zone between $15^{\circ} \mathrm{N}-40^{\circ} \mathrm{N}$ and $50^{\circ} \mathrm{W}-25^{\circ} \mathrm{W}$ allows us to see its influence on our study area located from $15^{\circ} \mathrm{N}$ onwards. We have seen in Figure 2, that the North High is on $15^{\circ} \mathrm{N}-40^{\circ} \mathrm{N}$ and $50^{\circ} \mathrm{W}-25^{\circ} \mathrm{W}$.

Figure 8 shows the first three PCs of Sea Level Pressure (SLP) data between $40^{\circ} \mathrm{S}-10^{\circ} \mathrm{S}$ and $40^{\circ} \mathrm{W}-0^{\circ} \mathrm{E}$ during summer (JAS) from 1979 to 2003 . $\mathrm{PC} 1$ is in a positive phase for the years 1979, 1988, 1990-1992, 1994-1995, 1995 and 2000-2001. It can be noted that the positive phase 2000-2001 corresponds to the return to normal rainfall over this region. These components represent $69.4 \%$ of the total variance. The PC2 of the SLP data was generally in its positive phase for the years 1981, 1983-1986, 1988, 1991-1992, 1995-1996, 1999 and 2001-2003, while the PC3 of the SLP data was in its positive phase between the years 1980-1983, 1991-1995, 1997 and 1999-2003 and in its negative phase between 1979, 1984-1990, 1996 and 1998. PC2 and PC3 account for about $12.5 \%$ and $8.9 \%$ of the total variance, respectively. The first three corresponding EOFs are shown in Figure 9.

Figure 9 shows the temporal component while Figure 10 shows the spatial component. The $\mathrm{PC} 1$ is positive or null over the whole area representing $69.4 \%$. The PC2 is negative between $26^{\circ} \mathrm{S}-40^{\circ} \mathrm{S}$. PC3 is positive between $30^{\circ} \mathrm{S}-10^{\circ} \mathrm{S}$ and $40^{\circ} \mathrm{W}-0^{\circ} \mathrm{E}$. We will now see the wavelet of the two SLP and precipitation in our study area. Figure 10 shows the average spectrum of wavelets over the period 1979 to 2003 of the SLP data between $15^{\circ} \mathrm{N}-40^{\circ} \mathrm{N}$ and $50^{\circ} \mathrm{W}-25^{\circ} \mathrm{W}$ during July August and September 1979-2003. There are peaks in the 4-year band in 1996-1999; oscillations of more than eight years in 1983-1990 and indicate intervals of high variance over the entire study period.

The average wavelet spectrum over the period 1979 to 2003 of the SLP data between $40^{\circ} \mathrm{S}-10^{\circ} \mathrm{S}$ and $40^{\circ} \mathrm{W}-0^{\circ} \mathrm{E}$ during July August and September 1979-2003 is shown in Figure 11. A 4-year variability is observed over the period 1989-1993. The figure shows an interval of high variance between 1979-1996 and low variance between 1997-2003. [30] suggested that the Pacific and Atlantic modes are analogous, governed by physics intrinsic to the ITCZ/cold tongue complex. This explains the mode of variability of more than 4 years.

Figure 12 shows the average wavelet spectrum over the period 1979 to 2003 of the GPCP precipitation data between $15^{\circ} \mathrm{N}-17^{\circ} \mathrm{N}$ and $17^{\circ} \mathrm{W}-13^{\circ} \mathrm{W}$ during July August and September for 1979-2003. There are fluctuations of 1 to 2 years from 1994-1995 and peaks of 8 years from 1984-1991. Interval of high variance (1984-2003) and low variance (1980-1984) are also noted in the figure. We can 


\section{SLP: JAS: 1979-2003}
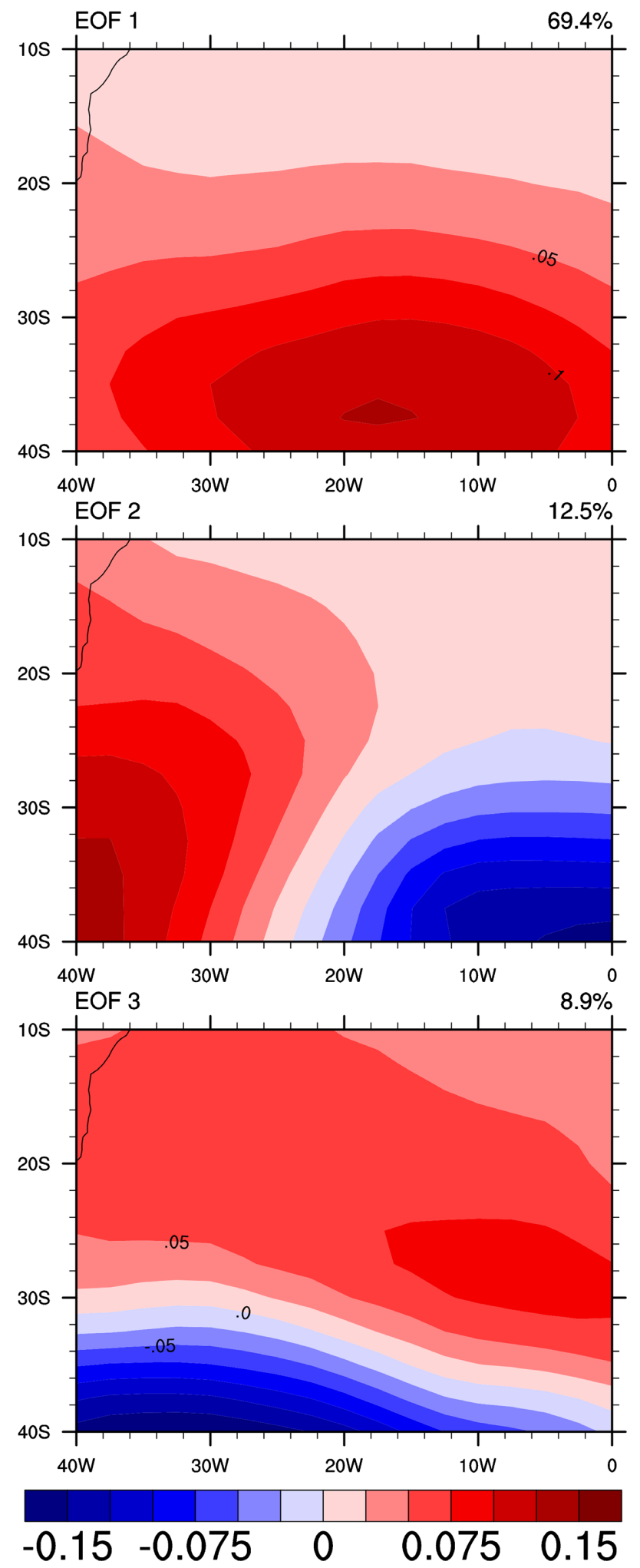

Figure 9. EOFs of SLP data between $40^{\circ} \mathrm{S}-10^{\circ} \mathrm{S}$ and $40^{\circ} \mathrm{W}-0^{\circ} \mathrm{E}$ during June, July and August 1979-2003. The percentage of the total variance explaining the pattern appears in the upper right corner. 

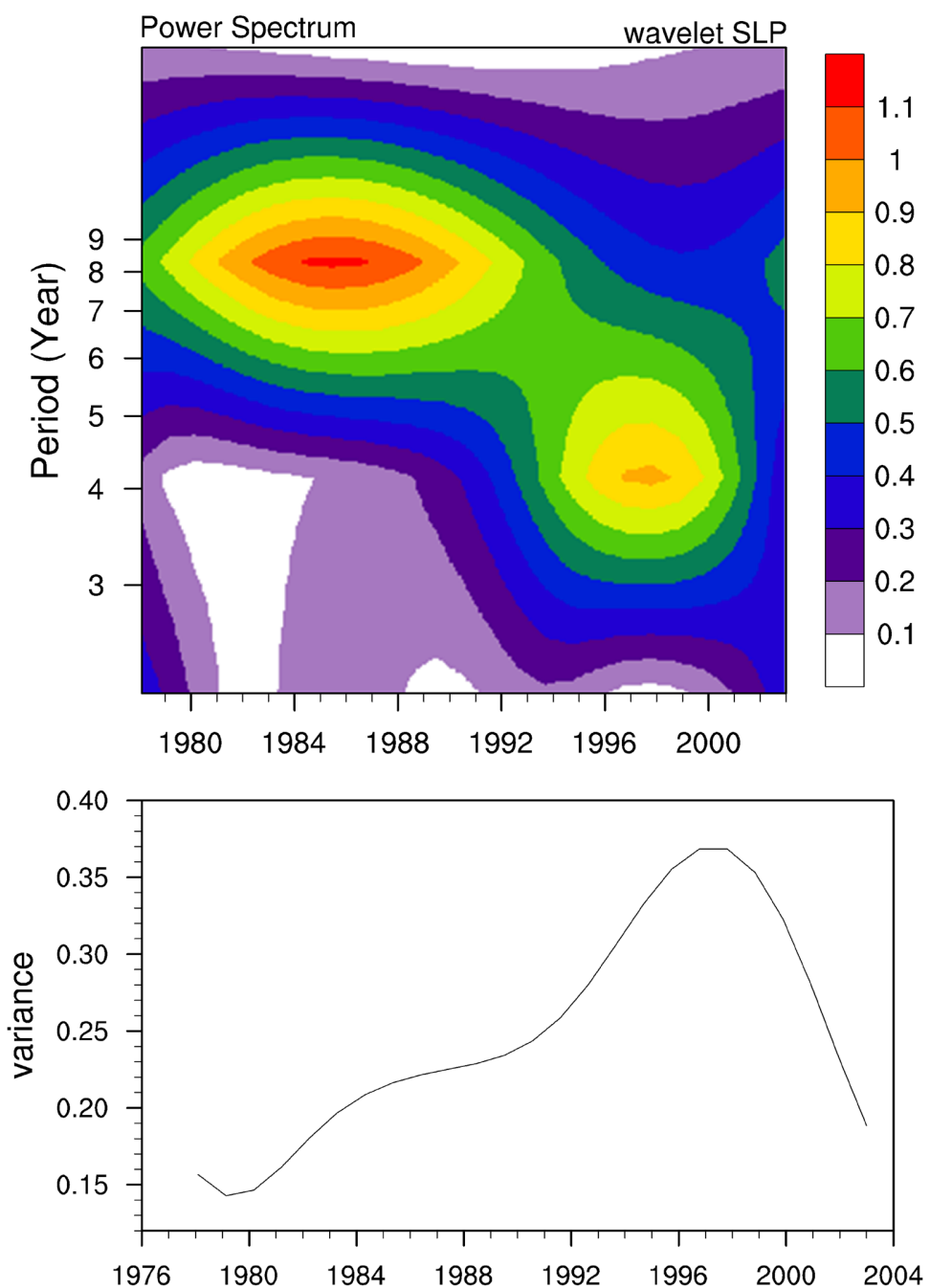

Figure 10. Average wavelet spectrum over the period 1979 to 2003 from the SLP data between $15^{\circ} \mathrm{N}-40^{\circ} \mathrm{N}$ and $50^{\circ} \mathrm{W}-20^{\circ} \mathrm{W}$ during July-August September (JAS) for 1979-2003.

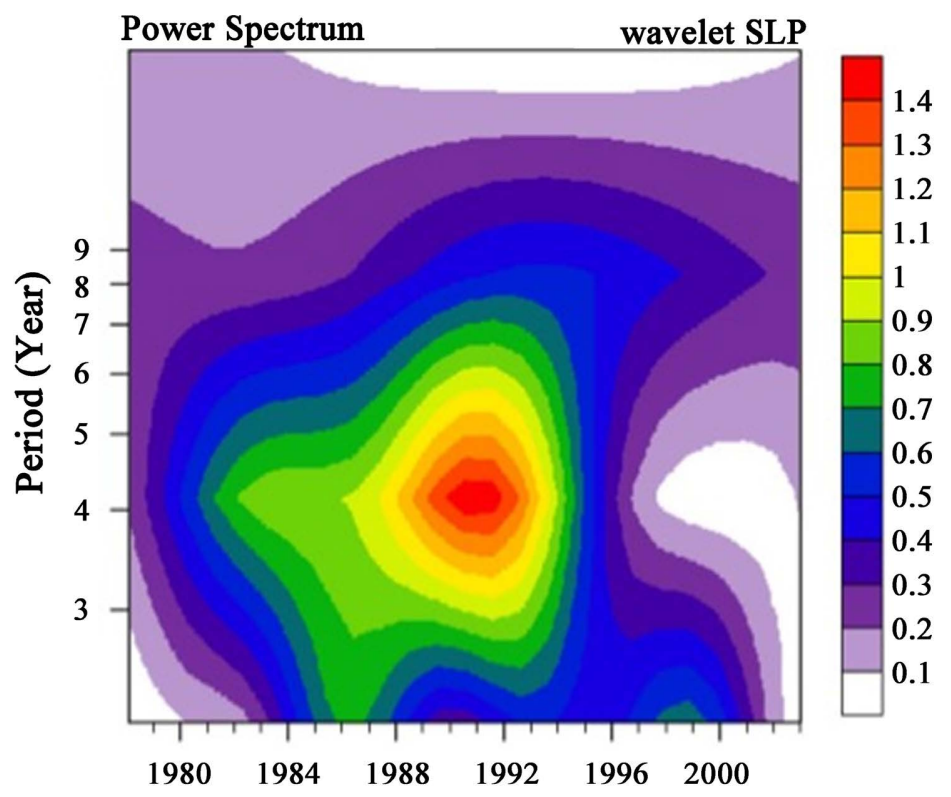




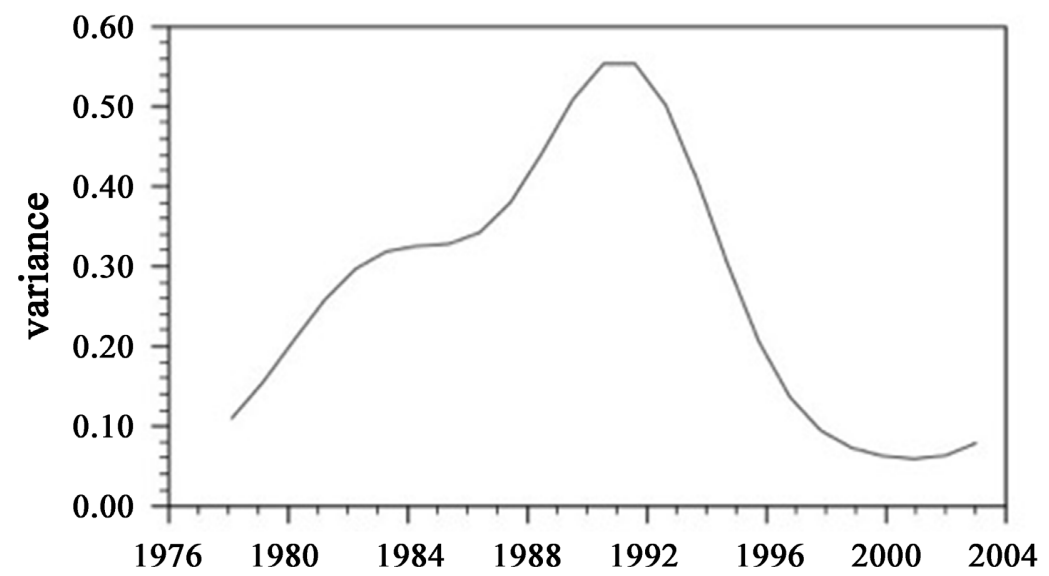

Figure 11. Average wavelet spectrum over the period 1979 to 2003 from SLP data between $40^{\circ} \mathrm{S}-10^{\circ} \mathrm{S}$ and $20^{\circ} \mathrm{W}-10^{\circ} \mathrm{E}$ during the months of July August and September 1979-2003.
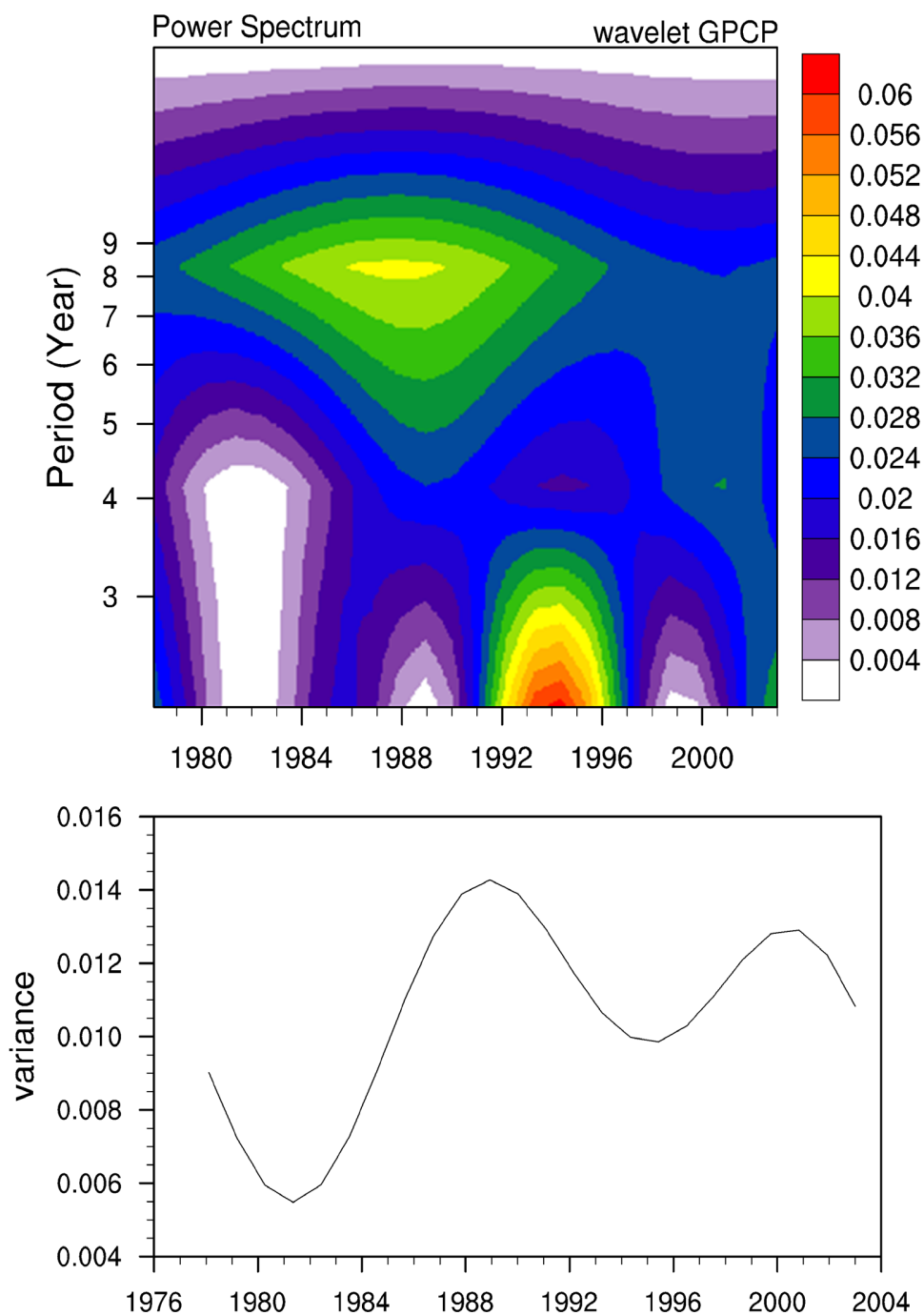

Figure 12. Average spectrum of wavelets over the period 1979 to 2003 from the GPCP precipitation data between $15^{\circ} \mathrm{N}-17^{\circ} \mathrm{N}$ and $17^{\circ} \mathrm{W}-12^{\circ} \mathrm{W}$ during July, August and September 1979-2003. 
conclude that the eight-year oscillations observed in 1984-1991 on the Precipitation data are in phase with the same duration's oscillations with the SLP data of the northern anticyclones. Fontaine et al. (1998) showed that a warm phase of Enoa type tends to move Walker cell eastward, which causes an abnormal upward transport over the Pacific and an abnormal subsidence transport over the peri-Atlantic space. The variability of more than 8 years is due to the El Nino phenomenon which is in phase with the North and South high ([29] [30]). [31] showed that there is a significant remote influence of the Pacific ENSO on the variability of the tropical Atlantic.

\section{Summary and Conclusions}

The most recent research on the interannual variability of the West African monsoon (time scale 1 - 15 years) has focused on oscillation sea surface temperature or pressure. It is shown that the maximum rainfall is accompanying the mean easterly wind of the northern hemisphere corresponding to the African Easterly Jet (AEJ) $(700 \mathrm{hPa})$ and the Tropical Easterly Jet (TEJ) $(200 \mathrm{hPa})$; the high pressure located at $25^{\circ} \mathrm{N}-40^{\circ} \mathrm{N}$ and $50^{\circ} \mathrm{W}-20^{\circ} \mathrm{W}$ is escorted from the wind subsidence at $700 \mathrm{hPa}$ and $200 \mathrm{hPa}$. We also found that sea level pressure (greater than or equal to $1015 \mathrm{hPa})$ is located between two zones $\left(10^{\circ} \mathrm{S}-40^{\circ} \mathrm{S}\right.$ and $40^{\circ} \mathrm{W}-0^{\circ} \mathrm{E}$ and $15^{\circ} \mathrm{N}-40^{\circ} \mathrm{N}$ and $50^{\circ} \mathrm{W}-25^{\circ} \mathrm{W}$ ). This zone is accompanied to the north by diverging winds at $700 \mathrm{hPa}$ and $200 \mathrm{hPa}$. It can be observed that in our study area $\left(15^{\circ} \mathrm{N}-17^{\circ} \mathrm{N}\right.$ and $\left.17^{\circ} \mathrm{W}-13^{\circ} \mathrm{W}\right)$ the wind rotation at $700 \mathrm{hPa}$ is north-easterly, i.e. with a negative sign, which is synonymous with a minimum of eddies, and that precipitation in our area is well related to SLP with the opposite sign.

We have shown the first three PC of Sea Level Pressure (SLP) data over $15^{\circ} \mathrm{N}$ $40^{\circ} \mathrm{N}$ and $50^{\circ} \mathrm{W}-25^{\circ} \mathrm{W}$ during summer (JAS) from 1979 to 2003. PC1 accounted for $62.2 \%$ of the total variance and was generally in its negative phase between 1979-1984, 90-94, 1996-1997, and 2002. PC2 of SLP were generally in its positive phase over our study area between 1981, 1983, 1986-1987, 1991-1994, 1997 and 2002; while PC3 of pressure was in its negative phase between 1979-1981, 1984, 1987-1988, 1990, 1993, 1995-1998 and 2000 and in its positive phase between 1982-1983, 1985-1986, 1989, 1991-1992, 1994, 1999 and 2001-2003. PC2 and PC 3 account for about $54.2 \%$ and more than $6.5 \%$ of the total difference, respectively. These positive phases of North Sea Level pressures (strengthening or southward shift of the Azores High) correspond to years of drought in the studied area due to a southward shift of the ITCZ.

We have also shown the first three PC of Sea Level Pressure (SLP) data over $40^{\circ} \mathrm{S}-10^{\circ} \mathrm{S}$ and $40^{\circ} \mathrm{W}-0^{\circ} \mathrm{E}$ during summer (JAS) from 1979 to 2003 . PC1s account for $69.4 \%$ of the total variance. PC1s of Sea Level Pressures were generally in its positive phase between 1979, 1988, 1990-1992, 1994-1995, 1995 and 2000-2001; while PC2s of pressures were in its positive phase 1981, 1983-1986, 1988, 1991-1992, 1995-1996, 1999 and 2001-2003. PC2 and PC3 account for about $12.5 \%$ and more than $8.9 \%$ of the total difference, respectively. These posi- 
tive phases of southern Sea Level Pressures (strengthening or northward shift of the St. Helena High) correspond to years of high rainfall in the studied due to a northward shift of the ITCZ. The variability lasting one year is the seasonal variability linked to the ITCZ. Its migration depends on the pressure fields' organisation, itself controlled by the thermal factor (sun) [32]. The role of the Atlantic appears to be the modulation of the north-south excursion of the Intertropical Convergence Zone (ITCZ). Since this zone is at the level of the Atlantic Ocean, it is, therefore, normal to see seasonal variability. This one-year variability related to the ITCZ is related to the temperatures of the North Tropical Atlantic (NTA) and then to the Azores High according to [3].

Wavelet power spectra and variance time series show interdecadal changes in 8 -years. Oscillations of eight (8) years on the precipitation data are in phase with oscillations of the same duration on the SLP data from northern highs. The positive phases of North Sea level pressure $\left(15^{\circ} \mathrm{N}-40^{\circ} \mathrm{N}\right.$ and $50^{\circ} \mathrm{W}-25^{\circ} \mathrm{W}$ ) (strengthening or southward displacement of the Azores High) is an unfavourable condition for rainfall in the northern zone of Senegal. This corresponds to a southward displacement of the ITCZ. On the other hand, the positive phases of Sea Level Pressures in the South $\left(40^{\circ} \mathrm{S}-10^{\circ} \mathrm{S}\right.$ and $40^{\circ} \mathrm{W}-0^{\circ} \mathrm{E}$ ) (strengthening or northward shift of the St. Helena High) correspond to years of heavy rainfall in the studied area.

\section{Conflicts of Interest}

The authors declare no conflicts of interest regarding the publication of this paper.

\section{References}

[1] Nicholson, S.E. (2013) The West African Sahel: A Review of Recent Studies on the Rainfall Regime and Its Interannual Variability. Meteorology, 2013, Article ID: 453521, 32 p. https://doi.org/10.1155/2013/453521

[2] Lambergeon, D. (1977) Relation entre les pluies et les précipitations en Afrique occidentale. PDEM No. 57, Agency for Aerial Navigation Safety in Africa and Madagascar, Dakar.

[3] Dieppois, B., Durand A., Fournier M., Massei N., Sebag D. and Hassane B. (2010) Variabilité des précipitations au sahel central et recherché du forçage climatique par analyse du signal: La station de Maine-Soroa (Niger) entre 1950 et 2005.

[4] Sultan, H. and Riemer, N. (2012) Relationship of Sahel Precipitation and Atmospheric Centers of Action. Advances in Meteorology, 2012, Article ID: 953853, 8 p. https://doi.org/10.1155/2012/953853

[5] Ropelewski, C.F. and Halpert, M.S. (1987) Global and Regional Scale Precipitation Patterns Associated with the El Niño/Southern Oscillation. Monthly Weather Review, 115, 1606-1626. https://doi.org/10.1175/1520-0493(1987)115\%3C1606:GARSPP\%3E2.0.CO;2

[6] Servain, J. (1991) Simple Climatic Indices for the Tropical Atlantic Ocean and Some Applications. Journal of Geophysical Research: Oceans, 96, 15137-15146. https://doi.org/10.1029/91JC01046 
[7] Zebiak, S.E. (1993) Air Sea Interaction in the Equatorial Atlantic Region. Journal of Climate, 6, 1567-158. https://doi.org/10.1175/1520-0442(1993)006\%3C1567:AIITEA\%3E2.0.CO;2

[8] Segele, Z.T., Lamb, P.J. and Leslie, L.M. (2008) Seasonal-to-Interannual Variability of Ethiopia/Horn of Africa Monsoon. Part I: Associations of Wavelet-Filtered Large-Scale Atmospheric Circulation and Global Sea Surface Temperature. Journal of Climate, 22, 3396-3421. https://doi.org/10.1175/2008JCLI2859.1

[9] Poccard, I., Camberlin, P., Richard, Y. and Roucou, P. (1998) Connexions des TSO du Pacifique et de l'Atlantique avec la dynamique atmosphérique et la pluviométrie en Afrique boréale. Proceedings of the Abidjan'98 Conference, IAHS Publication No. 252, Abidjan, November 1998, 35-44. https://researchgate.net

[10] Diakhaté, M., Lazar, A., De Coëtlogon, G. and Gaye, A.T. (2018) Do SST Gradients Drive the Monthly Climatological Surface Wind Convergence over the Tropical Atlantic? International Journal of Climatology, 38, e955-e965. https://doi.org/10.1002/joc.5422

[11] Huffman, G.J. (1997) The Global Precipitation Climatology Project Monthly Mean Precipitation Data Set. WMO/TD No. 808, World Meteorological Organization, Geneva, $37 \mathrm{p}$.

[12] Mccollum, J., Nelkin, E., Klotter, D., Berte, Y., Diallo, B.M., Gaye, I., Kpabeba, G., Ndiaye, O., Noukpozounkou, T.M.M., Thiam, A., Toure, A.A., Traore, K., Nicholson, S.E. and Some, B. (2003) Validation of TRMM and Other Rainfall Estimates with a High-Density Gauge Dataset for West Africa. Part I: Validation of GPCC Rainfall Product and Pre-TRMM Satellite and Blended Products. Journal of Applied Meteorology and Climatology, 40, 1355-1368.

https://doi.org/10.1175/1520-0450(2003)042\%3C1355:VOTAOR\%3E2.0.CO;2

[13] Dinku, T., Ceccato, P., Grover-Kopec, E., Lemma, M., Connor, S.J. and Ropelewski C.F. (2007) Validation of Satellite Rainfall Products over East Africa's Complex Topography. International Journal of Remote Sensing, 28, 1503-1526. https://doi.org/10.1080/01431160600954688

[14] Dee, D.P., Uppala, S.M., Simmons, A.J., Berrisford, P., Poli, P., Kobayashi, S., et al. (2011) The ERA-Interim Reanalysis: Configuration and Performance of the Data Assimilation System. Quarterly Journal of the Royal Meteorological Society, 137, 553-597. https://doi.org/10.1002/qj.828

[15] Torrence, C. and Compo, G.P. (1998) A Practical Guide to Wavelet Analysis. Bulletin of the American Meteorological Society, 79, 61-78. https://doi.org/10.1175/1520-0477(1998)079\%3C0061:APGTWA\%3E2.0.CO;2

[16] Von Storch, H., Zorita, E. and Cubasch, U. (1993) Downscaling of Global Climate Change Estimates to Regional Scale: An Application to Iberian Rainfall in Wintertime. Journal of Climate, 6, 1161-1171. https://doi.org/10.1175/1520-0442(1993)006\%3C1161:DOGCCE\%3E2.0.CO;2

[17] Ponater, M., Köning, W., Sausen, R. and Sielmann, F. (1994) Circulation Regime Fluctuation and Their Effect on Intraseasonal Variability in the ECHAM Climate Model. Tellus A, 46, 265-285. https://doi.org/10.3402/tellusa.v46i3.15478

[18] Kharin, V. (1995) The Relationship between Sea Surface Temperature Anomalies and Atmospheric Circulation in GCM Experiments. Climate Dynamics, 11, 359-375. https://doi.org/10.1007/BF00215737

[19] Busuioc, A., von Storch, H. and Schnur, R. (1999) Verification of GCM Generated Regional Seasonal Precipitation for Current Climate and of Statistical Downscaling Estimates under Changing Climate Conditions. Journal of Climate, 12, 258-272. 
[20] Puebla, R. and Nieto, S. (2009) Trends of Precipitation over the Iberian Peninsula and the North Atlantic Oscillation Under Climate Change Conditions. International Journal of Climatology, 30, 1807-1815. https://doi.org/10.1002/joc.2035

[21] Nicholson, S.E. and Grist, J.P. (2003) The Seasonal Evolution of the Atmospheric Circulation over West Africa and Equatorial Africa. Journal of Climate, 16, 1013-1030. https://doi.org/10.1175/1520-0442(2003)016\%3C1013:TSEOTA\%3E2.0.CO;2

[22] Crespo, L.R., Keenlyside, N. and Koseki, S. (2019) The Role of Sea Surface Temperature in the Atmospheric Seasonal Cycle of the Equatorial Atlantic. Climate Dynamics, 52, 5927-5946. https://doi.org/10.1007/s00382-018-4489-4

[23] Monerie, P.A., Roucou P. and Fontaine B. (2012) Mid-Century Effects of Climate Change on African Monsoon Dynamics Using the A1B Emission Scenario. International Journal of Climatology, 33, 881-896. https://doi.org/10.1002/joc.3476

[24] Janicot, S. and Fontaine, B. (1993) L'évolution des idées sur la variabilité interannuelle récente des précipitations en Afrique de l'Ouest. La Météorologie, 1, 28-53. https://doi.org/10.4267/2042/53332

[25] Sultan, B. (2011) L'étude des variations et du changement climatique en Afrique de l'Ouest et ses retombées sociétales.

[26] Leroux, M. (2001) The Meteorology and Climate of Tropical Africa. Springer, London, New York, 493 p.

[27] Monerie, P.-A. and Roukou, P. (2015) Impact du changement climatique sur les pluies de mousson d'Afrique de l'Ouest entre juin et octobre xviiie Colloque de l'Association Internationale de climatologie, Liège 2015.

[28] Suraud, P. (1954) Le front intertropical en Afrique occidentale Annuaire hydrologique de la France.

https://horizon.documentation.ird.fr/exl-doc/pleins_textes/divers11-12/16841.pdf

[29] Chiang, J.C.H. and Vimont, D.J. (2004) Analogous Pacific and Atlantic Meridional Modes of Tropical Atmosphere-Ocean Variability. Journal of Climate, 17, 4143-4158. https://doi.org/10.1175/JCLI4953.1

[30] Fontaine, B., Trzaska, S. and Janicot, S. (1998) Evolution of the Relationship between Near Global and Atlantic SST Modes and the Rainy Season in West Africa: Statistical Analyses and Sensitivity Experiments. Climate Dynamics, 14, 353-368. https://doi.org/10.1007/s003820050228

[31] Chang, P., Saravanan, R., Ji, L. and Hegerl, G.C. (2000) The Effect of Local Sea Surface Temperatures on Atmospheric Circulation over the Tropical Atlantic Sector. Journal of Climate, 13, 2195-2216. https://doi.org/10.1175/1520-0442(2000)013\%3C2195:TEOLSS\%3E2.0.CO;2

[32] Citeau, J., Finaud L., Cammas. J.P. and Demarq, H. (1989) Questions Relative to ITCZ Migrations over the Tropical Atlantic Ocean, Sea Surface Temperature and Senegal River Runoff. Meteorology and Atmospheric Physics, 41, 181-190. https://doi.org/10.1007/BF01026109 